\title{
Critical Thinking and Problem-Solving Skills of Visually Impaired Female National Judo Team Athletes
}

\author{
Sengul Demiral \\ Correspondence: Sengul Demiral, Trakya University, Edirne, Turkey. \\ Received: December 26, 2018 \\ Accepted: January 29, 2019 Online Published: January 29, 2019 \\ doi:10.11114/jets.v7i3S.4004 \\ URL: https://doi.org/10.11114/jets.v7i3S.4004
}

\begin{abstract}
A high level of critical thinking and problem-solving skills in visually impaired female national judo team athletes is an important factor in increasing their performance and for their high performance. The aim of this study was to examine critical thinking and problem-solving skills of visually impaired female national judo team athletes. The sample of the study was composed of visually impaired female athletes $(n=15)$ in 2015 national team. A Personal Information Form, the California Critical Thinking Disposition Inventory and the Problem Solving Inventory were used as data collection tools. The data obtained in this study were analyzed using SPSS 17 software. Evaluation of the data analysis revealed that there was no statistically significant difference among groups in total Problem Solving Inventory and Critical Thinking Disposition Inventory scores in terms of age group or age of starting judo ( $p>0.05$ ). There was no statistically significant relationship between total problem-solving and total critical thinking disposition scores of athletes ( $p>0.05$ ). As a result, judo coaches are thought to play an important role in the development of strategies for increasing athletes' problem-solving and critical thinking skills and in the development of their sporting performance, particularly in the development of high performance.
\end{abstract}

Keywords: problem solving, visually impaired judo, critical thinking, performance, skill

\section{Introduction}

The importance given to thinking skills in education has increased in recent times. The best known thinking skills may be listed as scientific thinking, critical thinking, problem solving, analytical thinking, and inductive and deductive thinking (Özden, 2000; 2006; Cantürk and Başer, 2009). It is stated in the literature that thinking skills can be seen to range from basic to complex, such as remembering, basic thinking, critical thinking and creative thinking. Critical thinking is an effective method in stimulating knowledge generation. In the teaching process, critical thinking is an indispensable part of education (Norris, 1985). A number of definitions of critical thinking have been made by different scientists. They have defined critical thinking as reaching conclusions based on observation and information, or as deciding what we are to believe in and what we are to do (Paul et al., 1989; Lipman, 1988).

Critical thinking is a skill that an individual need to possess in every area. In the education process, problem-solving and critical thinking skills are important outcomes. As in the education process, in sporting performance, too, athletes are expected to develop critical thinking and problem-solving skills in order to acquire an attitude for a competitive strategy and to widen their perspective. Critical thinking is the process of interpreting and evaluating existing information in order to fully understand a problem before deciding about that problem (Kökdemir, 2003), whereas the problem-solving skill is the ability to apply a solution to a problem by acquiring the information that will lead the person to the solution and combining it so that it is ready for use.

Critical thinking consists of the concepts of problem solving, making decisions, making inferences, different thinking, evaluative thinking and logic (Koh, 2002). It is widely accepted that individuals with high levels of critical thinking skills are also effective problem-solving individuals (Kökdemir, 2003; Türnüklü and Yeşildere, 2005). The stages of problem solving are classified in different ways in the literature. Several of these definitions are included below.

Problem-solving skills are examined as the natural or artificial existence of a problem, defining the problem and determining its limits, conducting preliminary work towards a solution, developing suggestions for a solution and testing these suggestions, achieving results and making inferences regarding the results (Tay, 2002). Problem solving is defined as an individual's cognitive, affective and behavioral processes for solving difficulties that they encounter (D'Zurilla and Nezu, 1990; Kiremitci et al., 2014). Generally, a problem may be explained as a difficulty that one wishes to eliminate or 
a question to which an answer is sought (Türkçapar, 2009; Aksu, 1984). As a process, the problem-solving method includes certain methods such as trial and error, gaining insight and finding cause-and-effect relationships (Karaçam and Pulur, 2016; Dağl1, 2004; Sönmez, 2008). Besides its affective and behavioral features, problem solving is a complex process in which cognitive abilities are involved. Due to its cognitive characteristics, problem solving cannot be directly observed. Therefore, the problem-solving process begins by perceiving a situation as a problem and includes the best choice among others.

In the field of education, there are many researchers and studies that state the necessity for students to be educated with regard to critical thinking skills and dispositions and for students' acquisition of critical thinking skills and dispositions to be included among the basic aims of teaching programs (Yıldırım and Yalçın, 2008; Feuerstein, 1999; Paul et al., 1989; Tan, 1989).

In the field of physical education and sport, the instructional models in education are configured within a structure based on psychomotor development and physical activities. In the field of physical education, 8 different instructional models are defined, namely "direct instruction", "personalised system for instruction", "cooperative learning", "sport education", "peer teaching", "inquiry teaching", "tactical games", and "teaching personal and social responsibility" (Metzler, 2005). In Mosston and Ashworth's (2002) teaching styles, the five styles in the presentation approach are named as Command (Style A), Practice (Style B), Reciprocal (Style C), Self-Check (Style D) and Inclusion (Style E) respectively, while the six styles in the discovery approach are discussed as Guided Discovery (Style F), Problem Solving: Convergent Discovery (Style G), Problem Solving: Divergent Discovery (Style H), Learner-Designed (Style I), Learner-Initiated (Style J) and Self-Teaching (Style K) respectively. The transition from the command style (A) in the presentation method towards individual study in the discovery method $(\mathrm{K})$ is regarded as a transition from teacher-centeredness to learner-centeredness (İnce, 2010).

\section{Critical thinking and problem solving in sport and teaching of sporting skills}

One of the methods used in the development of critical thinking and problem-solving skills is sport. Critical thinking is "reflective thinking that is used to make reasonable and defensible decisions about movement" (McBride \& Cleland, 1998). In sports training, making a movement displayed by a trainer or specialist or reacting to the feedback given may create limitations in the area of sporting skills and cognitive development. Therefore, the need for cognitive difficulties to interact with activities aimed at developing sporting skill makes critical thinking vital in the field of physical education and sport (Saçl1, 2008). In physical education lessons and branch-specific sports training, sports students must not be expected to acquire and use critical thinking dispositions by themselves. Physical education instructors and branch coaches must possess the skill and knowledge to make this possible and to create this opportunity for sports students.

When considering the basic principles of the sport of judo in particular (minimum energy and maximum work generation) and its high-performance implementation, critical thinking ability and problem-solving skills play an effective role. Therefore, in parallel with the importance given to thinking skills in education in recent times, their implementation in sports training is also becoming increasingly important.

The best known thinking skills are scientific thinking, critical thinking, problem solving, analytical thinking, and inductive and deductive thinking (Cantürk and Başer, 2009). For trainers and coaches, the use of thinking skills in the basic teaching of judo and in the learning and implementation of judo techniques is very important. In a competitive environment, these skills are important performance indicators that can positively or negatively affect performance according to how they are used. Therefore, cognitive, critical and analytical thinking and problem-solving skills, into which thinking skills are classified, are only some of the skills that directly affect competitive performance in judo.

As well as being one of the points emphasised by educational scientists, the importance of problem-solving skills, which play an important role in success, is also stressed by sports scientists in the field of sports science. Particularly in studies of high performance, they are regarded as one of the important skills affecting success.

If information about why knowledge is learnt and how it is to be applied and used in the judo training system is not given, the occurrence of problems in the implementation of strategic plans for athletes' technical and tactical skills to be developed in competition will have a negative effect on performance.

The basic principle of judo is "maximum efficient use of mind and body". With another definition, it is the ability to do maximum work with minimum energy. At this point, the ability to use the mind and body in the most productive way comes into play (http://kodokanjudoinstitute.org/en/doctrine/purpose/Access:28/10/2018).

This is achieved with judo training discipline that takes years. The critical thinking and problem-solving skills used are only some of the skills used in developing this ability. These skills play an effective role in implementing the strategies and tactics required by judo athletes during competition.

In conclusion, critical thinking ability and problem-solving skills are only two of the important concepts occurring in 
sport. Critical thinking ability and problem-solving skills are not only important in academic environments, but also on every platform related to solving problems (Braman, 1999). One of these platforms is that of high performance in sport. Among the cognitive sciences, basic critical thinking skills are among the characteristics that allow athletes to display the best performance when under intense pressure (http://thinkingforsuccess.com/critical-thinking-in-sports.html). Moreover, these skills, applied to learning and implementing techniques and to a competitive environment, are only some of the skills that can positively and/or negatively affect performance. This is seen in many studies in the literature.

In this context, this study is structured to examine the critical thinking and problem-solving skills of visually impaired female judo athletes performing at a high level in the national team.

\section{Method}

The data obtained in this study were analyzed using SPSS 17 software. When checking for normal distribution of the variables, the Shapiro-Wilk test was used because of the number of units. When interpreting the results, 0.05 was used as the level of significance; it is stated that in the case of $\mathrm{p}<0.05$, the variables are not normally distributed, but in the case of $\mathrm{p}>0.05$, the variables are normally distributed. In the analysis of the differences between the groups, independent t-test and one-way ANOVA were used when the variables were normally distributed. When significant differences were observed with one-way ANOVA, LSD and Tukey's HSD tests were used in cases where the variances between the groups were homogeneous, while Tamhane's test was used in cases where variances were not homogeneous. When examining the differences between the groups, the Mann-Whitney $U$ test was used when the variables were not normally distributed.

\section{Calculating Cronbach's Alpha}

Cronbach's Alpha test is used for reliability. The data gathered from the 15 participants were used for the analysis. The Cronbach alpha value for the "Critical Thinking Scale" total is 0.611 and the Cronbach alpha value for the "Problem Solving Inventory" is 0.713 .

Table 1. Criteria for Cronbach's Alpha

\begin{tabular}{ll}
\hline Cronbach's Alpha & Reliability \\
\hline $0.80 \leq \alpha \leq 1.00$ & High Reliability \\
\hline $0.60 \leq \alpha \leq 0.80$ & Reliable \\
\hline $0.40 \leq \alpha \leq 0.60$ & Low Reliability \\
\hline $0.00 \leq \alpha \leq 0.40$ & Not Reliable \\
\hline
\end{tabular}

Table 2. Reliability test results

\begin{tabular}{lc}
\hline & Cronbach Alpha \\
\hline Critical Thinking Scale & 0.611 \\
\hline Problem Solving Inventory & 0.713 \\
\hline
\end{tabular}

\section{Results}

Table 3. Frequency and percentage table for categorical variables

\begin{tabular}{|c|c|c|c|}
\hline & & $\mathrm{n}$ & $\%$ \\
\hline \multirow[t]{2}{*}{ Gender } & Female & 15 & 100.0 \\
\hline & Total & 15 & 100.0 \\
\hline \multirow[t]{3}{*}{ Education Level } & High school and below & 8 & 53.3 \\
\hline & Bachelor's degree and above & 7 & 46.7 \\
\hline & Total & 15 & 100.0 \\
\hline \multirow[t]{3}{*}{ Age Group } & Under 25 & 7 & 46.7 \\
\hline & Over 26 & 8 & 53.3 \\
\hline & Total & 15 & 100.0 \\
\hline \multirow[t]{2}{*}{ Mother's Education Level } & Primary and Secondary & 15 & 100.0 \\
\hline & Total & 15 & 100.0 \\
\hline \multirow[t]{4}{*}{ Father's Education Level } & Primary and Secondary & 12 & 80.0 \\
\hline & High school & 1 & 6.7 \\
\hline & Bachelor's degree & 2 & 13.3 \\
\hline & Total & 15 & 100.0 \\
\hline \multirow{4}{*}{$\begin{array}{l}\text { Number of Years Spent } \\
\text { Doing Judo }\end{array}$} & $1-4$ years & 7 & 46.7 \\
\hline & $5-10$ years & 5 & 33.3 \\
\hline & Over 11 years & 3 & 20.0 \\
\hline & Total & 15 & 100.0 \\
\hline
\end{tabular}


The study was applied to visually impaired female athletes.

53.3 percent of the visually impaired women had at most a high school degree and 46.7 percent of them had at least a bachelor's degree.

53.3 percent of the visually impaired women were more than 26 years old and 46.7 percent of them were less than 25 years old.

All the athletes' mothers graduated from a primary or a secondary school.

80 percent of the athletes' fathers graduated from a primary or a secondary school, 6.7 percent of them graduated from a high school and 13.3 percent of them had a bachelor's degree.

46.7 percent of the athletes had spent 1-4 years, 33.3 percent of them had spent between 5-10 years and 20 percent of them had spent more than 11 years doing judo.

Table 4. Descriptive statistics for scale variables

\begin{tabular}{cccccc}
\hline & $\mathrm{n}$ & Mean & sd. & Min & Max \\
\hline Problem Solving Inventory & 15 & 71.80 & 13.07 & 49.00 & 90.00 \\
\hline Critical Thinking & 15 & 236.55 & 13.69 & 207.1 & 255.3 \\
\hline
\end{tabular}

Total scores for the "Problem Solving Inventory" ranged between $49-90$ and their mean was 71.80 . Total scores for the "Critical Thinking Scale" ranged between 207.1 - 255.3 and their mean was 236.55.

Table 5. Normality test results for "Problem Solving" and "Critical Thinking" according to education level

\begin{tabular}{llcccccc}
\hline & Education Level & \multicolumn{3}{c}{ Kolmogorov-Smirnov $^{\mathrm{a}}$} & \multicolumn{3}{c}{ Shapiro-Wilk } \\
\cline { 2 - 8 } & statistic & $\mathrm{df}$ & $\mathrm{p}$ & statistic & $\mathrm{df}$ & $\mathrm{p}$ \\
\hline Problem Solving & $\begin{array}{c}\text { High school and } \\
\text { below }\end{array}$ & .295 & 8 & .039 & .778 & 8 & $\mathbf{. 0 1 6}$ \\
\cline { 2 - 8 } & $\begin{array}{c}\text { Bachelor's } \\
\text { degree and above }\end{array}$ & .350 & 7 & .010 & .740 & 7 & $\mathbf{. 0 1 0}$ \\
\hline Critical Thinking & $\begin{array}{c}\text { High school and } \\
\text { below }\end{array}$ & .145 & 8 & .200 & .972 & 8 & $\mathbf{. 9 1 7}$ \\
\cline { 2 - 8 } & $\begin{array}{c}\text { Bachelor's } \\
\text { degree and above }\end{array}$ & .262 & 7 & .157 & .805 & 7 & $\mathbf{. 0 4 6}$ \\
\hline
\end{tabular}

The normality assumption was checked before deciding on the statistical method that would be used for the analysis. At this stage we benefited from the Kolmogorov-Smirnov and Shapiro-Wilk tests. Since the sample size was less than 30, the results of the Shapiro-Wilk test were taken into account. The critical value was $\mathrm{p}=0.05$. According to the normality test results the data were accepted as normally distributed when $p>0.05$. Since the data pattern did not meet the normality assumption, the nonparametric Mann-Whitney test was used.

Table 6. Mann-Whitney test results for "Problem Solving" and "Critical Thinking" according to education level

\begin{tabular}{cccccccccc}
\hline & Education Level & $\mathbf{n}$ & Mean & sd. & Min & Max & Mean Rank & $\mathrm{Z}$ & $\mathrm{p}$ \\
\hline \multirow{2}{*}{$\begin{array}{c}\text { Problem } \\
\text { Solving }\end{array}$} & High school and below & 8 & 77.63 & 14.51 & 54.00 & 90.00 & 10 & -1.853 & 0.064 \\
\cline { 2 - 8 } & $\begin{array}{c}\text { Bachelor's degree and } \\
\text { above }\end{array}$ & 7 & 65.14 & 7.49 & 49.00 & 71.00 & 5.71 & & \\
\hline $\begin{array}{c}\text { Critical } \\
\text { Thinking }\end{array}$ & High school and below & 8 & 232.06 & 9.15 & 216.47 & 244.71 & 6.13 & -1.737 & 0.082 \\
\cline { 2 - 7 } & $\begin{array}{c}\text { Bachelor's degree and } \\
\text { above }\end{array}$ & 7 & 241.68 & 16.79 & 207.06 & 255.29 & 10.14 & & \\
\hline
\end{tabular}

There was not a statistically significant difference between the education levels of the athletes in terms of the total problem-solving score ( $p>0.05$ ). Although it was not statistically significant, the total score (77.63) for athletes who had at most a high school degree was greater than the total score (65.14) for athletes who had at least a bachelor's degree.

There was not a statistically significant difference between the education levels of the athletes in terms of the total critical thinking score ( $\mathrm{p}>0.05)$. Although it was not statistically significant, the total score (232.06) for athletes who had at most a high school degree was less than the total score (241.68) for athletes who had at least a bachelor's degree. 
Table 7. Normality test results for "Problem Solving" and "Critical Thinking" according to age group

\begin{tabular}{cccccccc}
\hline & Age Group & \multicolumn{3}{c}{ Kolmogorov-Smirnov } & \multicolumn{3}{c}{ Shapiro-Wilk } \\
\cline { 2 - 7 } & & statistic & $\mathrm{df}$ & $\mathrm{p}$ & statistic & $\mathrm{df}$ & $\mathrm{p}$ \\
\hline Problem Solving & Under 25 & .202 & 7 & $.200^{*}$ & .920 & 7 & $\mathbf{. 4 6 6}$ \\
\cline { 2 - 7 } & Over 26 & .173 & 8 & $.200^{*}$ & .954 & 8 & $\mathbf{. 7 4 8}$ \\
\hline Critical Thinking & Under 25 & .206 & 7 & $.200^{*}$ & .920 & 7 & $\mathbf{. 4 7 0}$ \\
\cline { 2 - 7 } & Over 26 & .215 & 8 & $.200^{*}$ & .927 & 8 & $\mathbf{. 4 8 6}$
\end{tabular}

The normality assumption was checked before deciding on the statistical method that would be used for the analysis. At this stage we benefited from the Kolmogorov-Smirnov and Shapiro-Wilk tests. Since the sample size was less than 30, the results of the Shapiro-Wilk test were taken into account. The critical value was $\mathrm{p}=0.05$. According to the normality test results the data were accepted as normally distributed when $p>0.05$. Since the data pattern met the normality assumption, the independent $t$ test was used.

Table 8. Independent $t$ test results for "Problem Solving" and "Critical Thinking" according to age group

\begin{tabular}{lcccccccc}
\hline & Age Group & $\mathrm{n}$ & Mean & sd. & Min & Max & $\mathrm{t}$ & $\mathrm{p}$ \\
\hline Problem Solving & Under 25 & 7 & 75.71 & 12.38 & 54.00 & 89.00 & 1.092 & 0.295 \\
\cline { 2 - 8 } & Over 26 & 8 & 68.38 & 13.48 & 49.00 & 90.00 & & \\
\hline Critical Thinking & Under 25 & 7 & 237.65 & 10.78 & 225.88 & 255.29 & 0.281 & 0,783 \\
\cline { 2 - 7 } & Over 26 & 8 & 235.59 & 16.52 & 207.06 & 255.29 & & \\
\hline
\end{tabular}

There was not a statistically significant difference between the age groups of the athletes in terms of the total problem-solving score ( $>0.05)$. Although it was not statistically significant, the total score (75.71) for athletes who were under 25 years old was greater than the total score (68.38) for athletes who were more than 26 years old.

There was not a statistically significant difference between the age groups of the athletes in terms of the total critical thinking score ( $>0.05)$. Although it was not statistically significant, the total score (237.65) for athletes who were under 25 years old was greater than the total score (235.59) for athletes who were more than 26 years old.

Table 9. Normality test results for "Problem Solving" and "Critical Thinking" according to number of years spent doing Judo

\begin{tabular}{|c|c|c|c|c|c|c|c|}
\hline & \multirow{2}{*}{$\begin{array}{l}\text { Number of Years } \\
\text { Spent Doing Judo }\end{array}$} & \multicolumn{3}{|c|}{ Kolmogorov-Smirnov ${ }^{\mathrm{a}}$} & \multicolumn{3}{|c|}{ Shapiro-Wilk } \\
\hline & & statistic & df & $\mathrm{p}$ & statistic & $\mathrm{df}$ & $\mathrm{p}$ \\
\hline \multirow[t]{3}{*}{ Problem Solving } & $1-4$ years & .235 & 7 & $.200^{*}$ & .899 & 7 & .322 \\
\hline & $5-10$ years & .210 & 5 & $.200^{*}$ & .917 & 5 & .514 \\
\hline & Over 11 years & .349 & 3 & & .832 & 3 & .194 \\
\hline \multirow[t]{3}{*}{ Critical Thinking } & $1-4$ years & .199 & 7 & $.200^{*}$ & .962 & 7 & .836 \\
\hline & $5-10$ years & .212 & 5 & $200^{*}$ & .940 & 5 & .665 \\
\hline & Over 11 years & .362 & 3 & & .805 & 3 & .125 \\
\hline
\end{tabular}

The normality assumption was checked before deciding on the statistical method that would be used for the analysis. At this stage we benefited from the Kolmogorov-Smirnov and Shapiro-Wilk tests. Since the sample size was less than 30, the results of the Shapiro-Wilk test were taken into account. The critical value was $p=0.05$. According to the normality test results the data were accepted as normally distributed when $p>0.05$. Since the data pattern met the normality assumption, the One-Way ANOVA test was used.

Table 10. One-Way ANOVA test results for "Problem Solving" and "Critical Thinking" according to number of years spent doing Judo

\begin{tabular}{|c|c|c|c|c|c|c|c|c|}
\hline & Judo Age & $\mathrm{n}$ & Mean & sd. & Min & Max & $\mathrm{F}$ & $\mathrm{p}$ \\
\hline Problem & 1-4 years & 7 & 79.86 & 9.81 & 65.00 & 90.00 & 3.922 & 0.049* \\
\hline \multirow[t]{2}{*}{ Solving } & 5-10 years & 5 & 67.40 & 12.99 & 54.00 & 86.00 & & \\
\hline & Over 11 years & 3 & 60.33 & 9.87 & 49.00 & 67.00 & & \\
\hline \multirow{3}{*}{$\begin{array}{c}\text { Critical } \\
\text { Thinking }\end{array}$} & $1-4$ years & 7 & 239.66 & 8.80 & 227.06 & 255.29 & 0.529 & 0.602 \\
\hline & $5-10$ years & 5 & 231.29 & 11.18 & 216.47 & 243.53 & & \\
\hline & Over 11 years & 3 & 238.04 & 26.89 & 207.06 & 255.29 & & \\
\hline
\end{tabular}

There was a statistically significant difference between the lengths of time the athletes had spent doing judo in terms of the total problem-solving score $(\mathrm{p}<0,05)$. The total score for athletes who had spent between 1-4 years was greater than that of the athletes who se age ishad spent more than 11 years doing judo. 
There was not a statistically significant difference between the lengths of time the athletes had spent doing judo in terms of the total critical thinking score ( $p>0.05$ ).

Table 11. Correlation test results regarding the relation between "Problem Solving" and "Critical Thinking" variables"

\begin{tabular}{llcc}
\hline & & Problem Solving & Critical Thinking \\
\hline Problem Solving & $\mathrm{r}$ & 1.000 & .026 \\
\cline { 2 - 4 } & $\mathrm{p}$ &. & .927 \\
\hline Critical Thinking & $\mathrm{r}$ & .026 & 1.000 \\
\cline { 2 - 4 } & $\mathrm{p}$ & .927 &. \\
\hline
\end{tabular}

There was not a statistically significant correlation between the total scores for problem solving and critical thinking $(\mathrm{p}>0.05)$.

\section{Discussion and Conclusion}

For the development of sporting performance and for an athlete to continually display the best performance, awareness of the physiological, psychological and mental processes during good performance is important. It is observed that the critical thinking and problem-solving skills involved in these processes are discussed in this study.

When considering studies in the literature that examine the mutual relationships between problem-solving skills and personality traits, it is stated that personality traits have a positive impact (Karabulut \& Kuru, 2009). Therefore, it is considered that with regard to sporting career plans, it will be more effective if educators also pay attention to individuals' personality traits.

One of the studies conducted on the subject of problem-solving skills is the study examining the problem-solving skills and sporting confidence levels of judo athletes at the Trabzon Olympic Preparation Center. In the study, it was determined that the problem-solving skills of the judo athletes differed significantly according to the gender variable (Öztürk et al., 2016). This shows that the difference in gender that made a difference to the problem-solving skills of the judo athletes in their high performance efforts needs to be taken into consideration.

Known as a clinical practice, neurofeedback is a psychophysiological procedure within the framework of biofeedback that deals with training brain signals (Aktop \& Seferoğlu, 2014). It is predicted that with procedures like biofeedback and neurofeedback, problem-solving skills and critical thinking ability will also be able to contribute to high performance efforts. Therefore, it will be beneficial to widen its area of application. Moreover, the basic principle of judo is "maximum efficient use of mind and body". With another definition, it is the ability to do maximum work with minimum energy. The basic principles of judo are 'Jita-Kyoei' and 'Seiryoku-Zenyo'. While Jita-Kyoei forms the basic educational principles that are important in the mental maturation of an individual (respect, kindness, distillation, self-control, cooperation, honesty, friendship, patience, courage, modesty, seriousness), Seiryoku-Zenyo expresses the result of the development attained by an individual's continuous and regular exercises through the principle of "maximum work generation with minimum energy" (Stevens, 2013; Murata and Ross, 2005; Brousse and Matsumoto, 1999), while in training science, the sport of judo, which is a 70\% anaerobic sport, is a sport which requires a high level of skill. The determined characteristics that athletes competing in this sport are expected to have are development of analytical functions and the competitor's rapid perception and movement quality in continually changing conditions. Furthermore, the decisions made by athletes in a complicated game situation are related to their qualities for perceiving external stimuli. Levels of rapid thinking and interpretation are factors in preventing an opponent from making a successful tactical move or assisting one's own team in making a successful move (Bompa, 2007). When considered from this point of view, it is predicted that biofeedback and neurofeedback will have a significant effect on performance.

In a study conducted on the effect of imaging studies on problem-solving ability, it was determined that they have positive effects on the development of this skill (Aldemir et. al., 2014). This forms an example of how it can be effectively used in the development of sporting performance, especially of high performance.

In a study involving preservice physical education teachers, it was revealed that their critical thinking levels were low. Whilst the participants' critical thinking levels did not significantly differ according to the gender variable, they did significantly differ according to the variable of mother's and father's education level (Korur et al., 2016). It can be predicted that since critical thinking skills were low in these teacher candidates, who will teach sport and develop their students' sporting skills in the future, they will not be able to efficiently implement teaching programmes that will develop critical thinking skills, nor will they be able to create opportunities for development of these skills, in the students they are to train.

Moreover, in a study conducted on problem-solving skills among physical education teachers and other branch teachers, it was found that in terms of total scores for perceiving problem-solving skills, although no significant differences were found between physical education teachers and the other branch teachers, the mean scores of physical education teachers 
were found to be low compared to those of the other group. It was seen that physical education teachers needed to be given more attention with regard to their training on this subject (Pehlivan and Konukman, 2004). The best known thinking skills can be listed as scientific thinking, critical thinking, problem solving, analytical thinking, and inductive and deductive thinking (Özden, 2000; 2006; Cantïrk and Başer, 2009). It can be considered that development of these skills in physical education teachers and sports branch coaches will trigger development of these skills in the sports students that they teach. Moreover, it can be predicted that they will also be able to use the education programs that include these skills in an effective way.

In his study, Saçl (2008) suggested that teachers fell short in their use of teaching methods that would develop their students' critical thinking in lessons. Therefore, it is considered that enabling the flow of up-to-date information regarding the development of these methods through teachers' and trainers' in-service teaching programs will contribute to the education of sports students.

Similarly, it has been determined that since the training given to students is generally very theoretical, the students are passive, and insufficient opportunities are created for practice (activities requiring analysis, synthesis and evaluation ability), this training cannot contribute to critical thinking dispositions and levels (Korkmaz, 2009). These findings can be interpreted to indicate that since students in training programmes with physical education and sports teaching have low levels of critical thinking skills, the situations specified above are also valid for preservice teachers and trainers in physical education and sports teacher training departments.

As a result of examining the critical thinking and problem-solving skills of visually impaired female judo athletes in the national team, the following conclusions were reached.

No statistically significant difference was found between education levels with regard to total "Problem Solving Inventory" scores of the athletes $(\mathrm{p}>0.05)$. Although the difference was not statistically significant, the mean "Problem Solving Inventory" scores of athletes with high school education and below (77.63) were higher than the mean "Problem Solving Inventory" scores of athletes with bachelor's degrees and above (65.14). No statistically significant difference was found between education levels with regard to total "Critical Thinking Disposition Inventory" scores of the athletes $(p>0.05)$. Although the difference was not statistically significant, the mean "Critical Thinking Disposition Inventory" scores of athletes with high school education and below (232.06) were lower than the mean "Critical Thinking Disposition Inventory" scores of athletes with bachelor's degrees and above (241.68).

No statistically significant difference was found between age groups with regard to total "Problem Solving Inventory" scores of the athletes $(p>0.05)$. Although the difference was not statistically significant, the mean "Problem Solving Inventory" scores of athletes in the 25 and under age group (75.71) were higher than the mean "Problem Solving Inventory" scores of athletes in the 26 and over age group (68.38). No statistically significant difference was found between age groups with regard to total "Critical Thinking Disposition Inventory" scores of the athletes ( $p>0.05$ ). Although the difference was not statistically significant, the mean "Critical Thinking Disposition Inventory" scores of athletes in the 25 and under age group (237.65) were higher than the mean "Critical Thinking Disposition Inventory" scores of athletes in the 26 and over age group (235.59).

A statistically significant difference was found among the groups' total "Problem Solving Inventory" scores with regard to number of years spent doing judo $(\mathrm{p}<0.05)$. The mean "Problem Solving Inventory" scores of athletes who had spent between 1-4 years doing judo (79.86) was significantly higher than the mean "Problem Solving Inventory" scores of athletes who had spent 11 years or more doing judo (60.33). No statistically significant difference was found among groups with regard to total "Critical Thinking Disposition Inventory" scores of the athletes in terms of the number of years they had spent doing judo ( $p>0.05)$.

No statistically significant difference was found between the total problem-solving scores of the athletes and their total critical thinking disposition scores ( $\mathrm{p}>0.05)$.

\section{Recommendations}

While critical thinking is regarded as a way of overcoming problems in our lives, it is also one of the methods that facilitates our acquisition of information. While critical thinking assists individuals in developing their inner strengths, in this way, it contributes towards increasing their self-confidence (Hudgins and Edelman, 1988; Demirhan et al., 2010). Studies revealing that there are significant parallel relationships among learning styles, critical thinking and sporting performance can be encountered in the literature (Ghazivakili, et al., 2014). When considering the importance of critical thinking and problem-solving skills for athletes in reaching high performance, it is recommended that in the basic training stages in their training periods, critical thinking and problem-solving skills are included in technical and tactical exercises and that the relevant teaching methods are employed.

Furthermore, it can be recommended that sports performance and high performance planning is organised by using 
teaching strategies that can increase problem-solving and critical thinking skills. This will support athletes, trainers and sports coaches aiming for sporting performance in their efforts to easily overcome the difficulties that they encounter in their careers, and will help them to make a difference with regard to interpreting, organising and utilising the knowledge and skills they possess in their fields.

\section{References}

Aksu, M. (1984). Proceedings 1. Philosophy and social sciences congress. Erzurum

Aktop, A., \& Seferoğlu, F. (2014). Neuro-Feedback in Sport Performance. Journal of Sport and Performance Studies, 5(2), 23-36.

Aldemir, Y. G., Biçer, T., \& Kale, E. K. (2014). Effects of Visualization on Problem Solving in Football Players. Journal of Sport and Performance Studies, 5(2), 37-45.

Bompa, T. O. (2007). Training Theory and Method of Sports 'Periodization', Sports Publishing, 2007, Ankara.

Brousse, M., \& Matsumoto, D. (1999). Judo: A Sport and A Way of Life, International Judo Federation.

Cantürk, G. B., \& Başer, N. (2009). The Effect of Problem Based Learning on Students' Critical Thinking Skills, Turkish Journal of Educational Sciences Spring, 7(2), 451-482

D'Zurilla, T. J., \& Nezu, M. (1990). Development and preliminary evaluation of the social problem solving. Psychological Assessment: A Journal of Consulting and Clinical Psychology, 2(2), 156-163. https://doi.org/10.1037/1040-3590.2.2.156

Dağl1, A. (2004). Problem solving and decision making. Journal of Electronic Social Sciences, 3(7), 41-49.

Demirhan, E., Beşoluk, Ş., \& Önder, İ. (2010). The Change in Academic Achievement And Critical Thinking Disposition Scores Of Pre-Service Science Teachers Over Time, Western Anatolia Journal of Educational Sciences (WAJES), Dokuz Eylul University Institute, Izmir, Turkey ISSN 1308-8971.

Feuerstein, M. (1999). Media Literacy in Support of Critical Thinking. Journal of Educational Media. 24 (1), 12-43. https://doi.org/10.1080/1358165990240104

Ghazivakili, Z., Nia, R. N., Panahi, F., Karimi, M., Gholsorkhi, H., \& Ahmadi, Z. (2014). The role of critical thinking skills and learning styles of university students in their academic performance. Journal of advances in medical education \& professionalism, 2(3), 95.

Hudgins, B. B., \& Edelman, S. (1988). Children's Self Directed Critical Thinking: A Model for Its Analysis and Two Examples. Journal of Educational Research, 81(5), 262-273. https://doi.org/10.1080/00220671.1988.10885834

İnce, M. L., \& Hünük, D. (2010). Physical education teachers experienced in the process of education reform and their perception of teaching styles and styles. Education and Science, 35(157).

Karabulut, E. O., \& Kuru, E. (2009) A Study on the Problem Solving Skills and Personality Characteristics of Ahi Evran University Physical Education Teaching Department Students in Terms of Various Variables.. Ahi Evran University Kırşehir Education Faculty Journal, 10(3).

Karaçam, A., \& Pulur, A. (2016). Identification the Relation between Active Basketball Classification Referees' Empathetic Tendencies and Their Problem Solving Abilities. Universal Journal of Educational Research, 4(8), 1912-1917. https://doi.org/10.13189/ujer.2016.040822

Kiremitci, O., \& Canpolat, A. M. (2014). The Role of Physical Education and Sports College Students in Determining Metacognitive Awareness and Problem Solving Skills of Multiple Intelligence Areas. Journal of Sport Sciences, 25(3), 118-126.

Koh, A. (2002). Towards a critical pedagogy: creating 'thinking schools' in Singapore, Journal of Curriculum Studies, 34(3), 255-264. https://doi.org/10.1080/00220270110092608

Korkmaz, Ö. (2009). The effect of education faculties on students' critical thinking trends and levels. Turkish Journal of Educational Sciences, 7(4), 879-902.

Korur, E. N., Öncü, E., Küçük, K. S. (2016). The Relationship between Critical Thinking and Empathic Tendency: The Example of Preservice Physical Education Teachers, Journal of Computer and Education Research, 4(8), ISSN: 2148-2896. (http:dergipark.ulakbilim.gov.tr/jcer) (www.joucer.com)

Kökdemir, D. (2003). Decision Making and Problem Solving in Uncertainty Cases, Ankara University, Institute of Social Sciences, PhD Thesis, Ankara.

Krulik, S., \& Rudnick, J. A. (1999). Innovative tasks to improve critical and creative thinking skills (Edited by Lee V. 
Stiff). Developing mathematical reasoning in grades K-12. 1999 Yearbook of National Council of Teachers of Mathematics, Reston, Virginia.

Lipman, M. (1988). Critical thinking: what can it be? Educational Leadership, 46(1), 38-43.

McBride, R. E., \& Cleland, F. (1998). Critical thinking in physical education. Journal of Physical Education, Recreation and Dance, 69 (7), 42-52. https://doi.org/10.1080/07303084.1998.10605593

Metzler, M. (2005). Instructional models for physical education (2nd ed.). Arizona: Holcomb Hathaway.

Mosston, M., \& Ashworth, S. (2002). Teaching physical education (3th ed.). Columbus : Merrill Pub. Co.

Murata, N., \& Ross, N. H. Mind over Muscle (writing from the founder of judo), Kodansha USA, 2005.

Özden, Y. (2000 Learning and teaching. Ankara: Pegem Publications.

Özden, Y. (2006). Learning to think, conference notes. http://bote.balikesir.edu.tr/ yozden/index.php?option=com_docman\&task=cat_view\&gid=28\&dir=DESC\&order= name\&limit $=5 \&$ limitstart $=0(15 / 03 / 2006)$.

Öztürk, A., Bayazıt, B., \& Gencer, E. (2016). Investigation of Empathic Tendency and Problem Solving Skills of Judo Athletes (Sample Of Center Of Olympic Preparation In Trabzon). Sstb International Refereed Academic Journal of Sports, Health \& Medical Sciences, (18).

Paul, B., (1990). Critical Thinking Skills. http://www.ncrel.org/sdrs/areas/issues/envrnmnt/drugfree/sa3crit.htm. $(10 / 10 / 2005)$.

Paul, R., Binker, A., Douglas, M., \& Adamson, K. (1989). Critical Thinking Handbook: High School. A Guide for Redesigning Instruction. Center for Critical Thinking and Moral Critique. Sonoma State University Rohnert Park, Ca 94928.

Pehlivan, Z., \& Konukman, F. Comparison of Physical Education Teachers and Other Branch Teachers in Terms of Problem Solving Skills.

Saçli, F. (2008). Determination and Comparison of Critical Thinking Levels of Students Studying in Physical Education and Sports Teaching Coaching and Recreation Programs. (Unpublished master's thesis). Hacettepe University / Institute of Health Sciences, Ankara.

Sönmez, V. (2008). Teaching principles and methods. 2. Printing. Ankara: Anı Publishing.

Stevens, J. The Way of Judo (A Portrait of Jigoro Kano \& His Students), Shambhala Boston \& London, 2013.

Tan, M. (1989). Dimensions and Problems in Democracy Education. Education for Democracy. Ankara: Turkish Education Association Publications.

Tay, B. (2002). Teacher, Inspector and Expert Opinions on the Effect of Collaborative Teacher in Developing Problem Solving Skills of 4th and 5th Grade Social Studies. Ankara: Hacettepe University Institute of Social Sciences (Unpublished Master Thesis).

Türkçapar, Ü. (2009). Problem Solving Skills of Physical Education Sports High School Students in Terms of Different Variables, Ahi Evran University Kırşehir Education Faculty Journal (KEFAD) 10(1), 129-139.

Türnüklü, E. B., \& Yeşildere, S. (2005). Problem, Problem Solving and Critical Thinking, Gazi Faculty of Education Journal, Volume 25, Say1 3, 107-123

Yıldırım, H. İ., \& Yalçın, N. (2008). The effect of science education on the problem solving skills of science teacher candidates based on critical thinking skills. Gazi University Journal of Gazi Faculty of Education, 28(3).

\section{Copyrights}

Copyright for this article is retained by the author(s), with first publication rights granted to the journal.

This is an open-access article distributed under the terms and conditions of the Creative Commons Attribution license which permits unrestricted use, distribution, and reproduction in any medium, provided the original work is properly cited. 